\title{
Characterization of Immunogenic Soluble Crude Proteins from Biomphalaria Pfeifferi Against Schistosoma mansoni
}

\author{
Kennedy M. Kuria ${ }^{1} \quad$ Sylvia A. Opiyo ${ }^{2 *}$ \\ 1.Department of Medical Laboratory Science, Murang'a University of Technology, Box 75-10200, Murang'a, \\ Kenya \\ 2.Department of Physical and Biological Sciences, Murang'a University of Technology, Box 75-10200, \\ Murang'a, Kenya
}

\begin{abstract}
Schistosomiasis is the second most prevalent tropical disease in the world after malaria. Chemotherapy and molluscicides which are the main methods of control do not give lasting protection as the disease continues to spread to other new regions. Previous studies have demonstrated the immunogenic properties of the digestive gland (DG), foot parts (FT) and the rest of body tissue (RT) soluble protein of Biomphalaria pfeifferi against Schistosoma parasite and therefore possible candidates for vaccine development against the parasite. However, information about the chemical composition of the soluble proteins is scanty. The objective of this study was to characterize and determine chemical composition of the DG and FT soluble proteins from Biomphalaria pfeifferi. A total of twelve compounds were identified using GC-MS. $N$-tert-butyl methylamine and penicillamine were present in both DG and FT soluble proteins. Butylamine S, valine, amino heptanoic acid, 1,1-dimethylamino-1 butane and valienamine were present in the DG soluble protein but were missing in the FT extracts. Tert-butylamine, heptylamine, cycloheptane methylamine, erythro- $O$-methylthreonine and leucine were present in the FT soluble protein but missing in the DG extracts. FTIR analysis showed $\mathrm{N}-\mathrm{H}$ stretch at $3100 \mathrm{~cm}^{-1}, \mathrm{C}=\mathrm{O}$ stretch at $1700 \mathrm{~cm}^{-1}$, $\mathrm{N}-\mathrm{H}$ bending at $1600 \mathrm{~cm}^{-1}$ and $\mathrm{O}-\mathrm{H}$ peak at $3500 \mathrm{~cm}^{-1}$ while UV absorption occurred at 240-300 nm thus confirmed the presence of amino acids in the soluble protein extracts. Results from this study justifies medicinal activity of Biomphalaria pfeifferi soluble crude protein extracts. Further studies involving isolation of individual constituents in the crude soluble proteins and subjecting them to bioassay is highly recommended.
\end{abstract}

Keywords: Schistosomiasis; Biomphalaria pfeifferi; Protein extracts; Chemical compounds

DOI: $10.7176 / \mathrm{JNSR} / 10-12-03$

Publication date:June 30th 2020

\section{Introduction}

Schistosomiasis is an acute and chronic parasitic disease caused by blood flukes (trematode worms) of the genus Schistosoma (Jauréguiberry et al. 2010). It is the second most prevalent tropical disease in the world after malaria and World Health Organization estimated the annual death rate at 200,000 globally (WHO 2016). The disease is found mainly in developing countries in Africa, Asia, South America, the Middle East, and the Caribbean. More than 207 million people, $85 \%$ of whom live in Africa, are infected with schistosomiasis, and an estimated 700 million people are at risk of infection in 76 countries where the disease is considered endemic (WHO 2016). In Kenya, prevalence of the disease ranges from $5 \%$ to over $65 \%$ in different communities and contributes to significant morbidity. It is also estimated that 16 million people in 56 out of 158 districts are at risk of the disease and over 9.1 million are infected in the country (Odhiambo et al. 2014). Schistosomiasis mostly affects poor and rural communities, particularly agricultural and fishing populations. Women doing domestic chores in infested water, such as washing clothes, are also at risk and can develop female genital schistosomiasis. Inadequate hygiene and contact with infected water make children especially vulnerable to infection (WHO 2016). Currently, chemotherapy and molluscicides are used to control schistosomiasis, however, they do not give lasting protection as the disease continues to spread to other new regions and risk of re-infection. Vaccine would be cost-effective alternative way for the control of schistosomiasis.

Nature has provided a large source of medicinal agents and traditional medicine systems continues to play an essential role in healthcare, with about $80 \%$ of the world's population still relying on traditional medicines for primary healthcare (Owolabi et al. 2007; Opiyo 2009, 2019, Ndirangu et al. 2020a, 2020b). The search for antiinfective agents from natural origin has led to the discovery of novel drug candidates used against diverse diseases (Manguro et al. 2009, 2010a, 2010b; Opiyo 2011a, 2011b, 2015, 2017; Jeruto et al. 2017; Ochung et al. 2018; Makenzi et al. 2019a; 2019b). Over 50\% of all modern clinical drugs are of natural product origin (Newman et al. 2003; Ochung et al. 2015; Ochieng et al. 2013, 2017; Njoroge \& Opiyo 2019a, 2019b). Continued research aimed at determination of chemical composition of natural products is important for the discovery new sources of bioactive principle for drugs and vaccine development.

Snails have been used both as a food and as a treatment for a variety of medicinal conditions (Ulagesan \& Kim 2018). Snail meat has medicinal value and is used to treat ailments such as whooping cough, anaemia, asthma and high blood pressure (Ebenebe 2000). Extracts from fresh water and land snail species namely Achatina fulica, 
Cryptozona bistrialis, Pila globosa, Pila virens, Bellamya dissimilis, Bithynia (Digoniostoma) pulchella and Melanoides tuberculate showed antibacterial and antifungal activities (Ulagesan \& Kim 2018). Extracts from African giant snail (Archachatina marginata) caused agglutination of certain pathogenic bacteria and exhibited anti-tumor properties (Lawal et al. 2015). Haemolymph of A. marginata showed hepatoprotective effect and produce a dose dependent effect on haematological and biochemical parameters when administered to albino rats (Lawal et al. 2015). Haemolymph from two species of giant African land snails (Archachatina marginata and Achatina achatina showed shaemagglutination potential (Abiona et al. 2014). Soluble proteins from Biomphalaria pfeifferi showed larvicidal activity against Artemia salina Leach (Kobia 2017).

Common antigens between different species of Schistosoma and their intermediate host have been reported (Khattab et al. 2010) providing a reason why the parasite is able to develop in this host. Soluble proteins from digestive gland (DG), foot parts (FT) and the rest of Biomphalaria pfeifferi body tissue (RT) showed immunogenic properties against the Schistosoma parasite (Kobia 2017; Kuria et al. 2019). Immunization of BALB/c mice with the soluble proteins from Biomphalaria pfeifferi caused worm reduction when the mice were challenged with the parasite (Kuria et al. 2012; Kobia 2017; Kuria et al. 2019). The soluble proteins also stimulated the production of effective cytokines, immunoglobulins and reduced hepatic pathology (Kuria et al. 2019). Despite the fact that the soluble proteins from Biomphalaria pfeifferi exhibit immunogenic effect and hence possible candidates for vaccine development to be used to control schistosomiasis, information about the chemical composition of the proteins is scanty. The objective of this study was to determine the chemical composition of the DG and FT soluble proteins from Biomphalaria pfeifferi.

\section{Materials and Methods}

\subsection{Collection and maintenance of snails}

Biomphalaria pfeifferi snails were collected from irrigation canals in Mwea in Kirinyaga sub-county in Kenya which is located between latitudes $0^{\circ} 36^{\prime} 0^{\prime \prime} \mathrm{S}$ and $0^{\circ} 44^{\prime} 0^{\prime} \mathrm{S}$ ' and longitudes $37^{\circ} 16^{\prime} 0^{\prime \prime} \mathrm{E}$ and $37^{\circ} 28^{\prime} 0^{\prime \prime} \mathrm{E}$. The snails were carried in plastic containers lined with damp cotton wool and transported to the Malacology Laboratory at the Institute of Primate Research (IPR) in Kenya. The snails were screened for schistosomes by exposing them to light (100 watts bulb shielded with glass to safeguard the snails from the heat) for two hours to check if any was shedding cercariae at interval of 30 minutes. Screening was carried out for five consecutive weeks and snails that were negative were housed in a temperature-controlled snail room at $26-28^{\circ} \mathrm{C}$, with 12 hours of light and 12 hours of darkness. Sand and gravel from the area where the snails were collected was sterilized by heating at $150^{\circ} \mathrm{C}$ for 12 hours then cooled and layered in plastic tanks. Snail water (chlorine free water from IPR well) was placed in the tanks three quarter full. Daphnia (tiny and semitransparent freshwater crustacean) was added for aeration and the screened cercariae negative snails were transferred into the tanks. The water was changed twice a week. Dried soft lettuces (dipped in hot water and dried in the oven) were placed into the snail tanks for the snails to feed on as described by Yole et al. (1996).

\subsection{Preparation of snail soluble crude proteins}

Foot and digestive gland were obtained from B. pfeifferi snails under a dissecting microscope. The snails were placed on a petri dish and exposed from its shell by crushing the shell using strong forceps. Using a scarpel the foot and the digestive glands were incised and placed in labeled eppendorf tubes containing phosphate buffered saline (PBS x1) as described in our laboratory (Kuria et al. 2012). The samples were homogenized using a glass motor and pestle. The homogenate was centrifuged for one hour at $14,000 \mathrm{~g}$ at $4^{\circ} \mathrm{C}$ and resulting supernatant assayed for protein concentration. Protein assay estimation was done in serial doubling dilution in microtitre plate where the BIO-RAD dye was added to the aliquots, then incubated for 1 hour. The protein concentrations were determined using ELISA reader at wavelength of $595 \mathrm{~nm}$ and was found to be $1.44 \mathrm{mg} / \mathrm{ml}$ for both foot and digestive gland soluble proteins. The protein extracts were stored at $-20^{\circ} \mathrm{C}$ until required.

\subsection{Gas chromatograph - mass spectrometer (GC-MS) analysis}

GC-MS analysis of DG and FT soluble crude protein extracts from B. pfeifferi was performed using GCMSQP2010SE gas chromatograph mass spectrometer machine coupled to gas chromatograph (GC-2010 plus) both manufactured by Shimadzu Corporation (Kyoto, Japan). The machine had two components: the chromatography component and the mass spectrometer component, equipped with MS fused silica capillary column $(30 \mathrm{~m}$ X 0.25 $\mathrm{mm}$ internal diameter and film thickness of $0.25 \mu \mathrm{m})$. In GC-MS spectroscopic detection, ionization energy of 70 $\mathrm{eV}$ was used. Helium gas (99.99\%) was used as carrier gas and was set between 5-9 bar and the chromatograph vacuum for mass transfer line and interface temperature oven programmed to heat at $40^{\circ} \mathrm{C}, 60{ }^{\circ} \mathrm{C}, 100^{\circ} \mathrm{C}, 130^{\circ} \mathrm{C}$ and $170{ }^{\circ} \mathrm{C}$ with $1 \mathrm{~min}$ interval. Diluted samples $(1 / 100 \mathrm{v} / \mathrm{v}$ in methanol and water) of $1 \mu \mathrm{l}$ were loaded in cuvettes which were inserted in an auto injector, A0C-201 (Shimadzu Corporation Kyoto, Japan) in the spit and the separation performed in the gas chromatograph followed by analysis using the mass spectrometer. The relative percentage of the chemical constituents in the soluble protein extracts were captured expressed and resolved using 
the GC-MS real time analyser software (GCMS Shimadzu Lab Solution) during the process and later using GC postrun analyser with an in-built library to compare the molecular masses to known compounds (NIST 2017).

\subsection{Fourier Transform Infrared (FTIR) Spectrometry Analysis}

The FT and DG soluble crude protein extracts were lyophilized using a lyophilizing machine. Solid potassium bromide $(\mathrm{KBr})$ was dried in an oven at more than $100^{\circ} \mathrm{C}$ to evaporate any water molecules in the salt. The samples of soluble protein extracts (FT and DG) were mixed with the $\mathrm{KBr}$ (IR grade) in the ratio of 1:100 and ground to fine powder using glass mortar and pestle. The mixture was then used to prepare thin pellets by compressing at 20 MPa using a hydraulic press machine (Biotech engineering management company limited, UK). The pellets were transferred to a pellet holder. The machine was run first without the sample to collect the background data. The pellets were then analysed using a 600 FTIR spectrometer (Biotech engineering management company limited, UK).

\subsection{Ultraviolet Spectroscopy}

UV spectroscopy was performed using the standard process. Briefly, using soluble protein extracts, a concentration of $1.4 \mathrm{mg} / \mathrm{ml}$ in double distilled water was prepared and each transferred into a clean cuvette (Precision cells inc, NY, USA). This was placed in a UV spectrophotometer (UV-1800, Shimadzu Corporation, Kyoto, Japan) and scanned between wavelength ranges of $200 \mathrm{~nm}$ and $700 \mathrm{~nm}$.

\section{Results and Discussion}

The chemical components of the DG and FT soluble crude proteins from B. pfeifferi (Tables 1 and 2) were determined using GC-MS based on their retention time and computer matching of the mass spectra with the library standard (NIST 2017). The chemical compounds identified from the soluble crude proteins consisted mainly on amines and amino acids. The DG extracts consisted of butylamine S (97\%), $N$-tert-butylmethylamine (92\%), valine (83\%), aminoheptanoic acid (74\%), L-valine (84\%) in absolute methanol, and 1,1-dimethylamino-1-butane $(88 \%), N$-tert-butylmethylamine $(82 \%)$, valienamine $(73 \%)$, penicillamine $(69 \%)$ and penicillamine $(82 \%)$ in water. In FT ectract, the major chemical components were found to be tert-butylamine $(96 \%), \mathrm{N}$-tertbutylmethylamine (87\%), heptylamine (91\%), penicillamine (81\%), penicillamine $(84 \%)$ in absolute methanol and cycloheptanemethylamine (83\%), N-tert-butylmethylamine (81\%), dl-erythro- $O$-methylthreonine $(73 \%)$ and leucine $(70 \%)$ in water.

$N$-tert-butyl methylamine and penicillamine were the only compounds that were present in both DG and FT soluble crude proteins. Butylamine $\mathrm{S}$, valine, amino heptanoic acid, 1,1-dimethylamino-1 butane and valienamine were present in the DG soluble protein extract but were missing in the FT extracts. Tert-butylamine, heptylamine, cycloheptane methylamine, erythro- $O$-methylthreonine and leucine were present in the FT soluble protein but missing in the DG extracts. Penicillamine is used to treat a wide range of medical conditions including copperassociated hepatitis, lead poisoning, Wilson disease and rheumatoid arthritis (Fieten et al. 2013). Penicillamine derivative S-nitro-N-acetyl-D, L-penicillamine has been implicated in antiparasitic action against the in vitro growth of Plasmodium falciparum, P. chabaudi and P. berghei. (Balmer et al. 2000) while its derivative penicillin is used as an antimicrobial agent (Ashraf et al. 2015). The results on chemical composition of DG of B. pfeifferi soluble protein are in agreement with previously reported data (Kobia 2017). Literature regarding the identified chemical composition of FT of the snail protein extracts are unavailable. This is the first report on the chemical composition of FT soluble protein of Biomphalaria pfeifferi.

FTIR spectra of DG and FT soluble crude protein (Figures 1 and 2) showed N-H stretch at $3100 \mathrm{~cm}^{-1}, \mathrm{C}=\mathrm{O}$ (Amide I) at $1700 \mathrm{~cm}^{-1}, \mathrm{~N}-\mathrm{H}$ bending (Amide II) at $1600 \mathrm{~cm}^{-1}$ and $\mathrm{O}-\mathrm{H}$ peak at $3500 \mathrm{~cm}^{-1}$. FT-IR spectroscopy has been widely used to study the structure of proteins and the results in this study concurred with literature report (Singh 1999). From the UV experiment (Figure 3) the soluble protein absorbed between wavelengths of 240 to $300 \mathrm{~nm}$ which was in agreement with previous reports (Fohely \& Suardi 2018). The FTIR and UV data confirmed the presence of amino acids in the soluble protein extracts. 
Table 1. Chemical composition of snail digestive gland (DG) soluble proteins extracts

\begin{tabular}{|l|c|c|c|c|c|c|}
\hline Extracts & Peak & $\begin{array}{c}\text { Retention } \\
\text { time }\end{array}$ & $\begin{array}{c}\text { Similarities } \\
(\%)\end{array}$ & Name of compound & $\begin{array}{c}\text { Molecular } \\
\text { formula }\end{array}$ & $\begin{array}{c}\text { Nature of } \\
\text { compound }\end{array}$ \\
\hline \multirow{4}{*}{$\begin{array}{l}\text { MG extract in } \\
\text { Methanol }\end{array}$} & 1 & 1.625 & 97 & Butylamine $\mathrm{S}$ & $\mathrm{C}_{4} \mathrm{H}_{11} \mathrm{~N}$ & Amine \\
\cline { 2 - 7 } & 2 & 2.195 & 92 & $\begin{array}{c}\text { N-tert- } \\
\text { Butylmethylamine }\end{array}$ & $\mathrm{C}_{5} \mathrm{H}_{13} \mathrm{~N}$ & Amine \\
\cline { 2 - 7 } & 5 & 3.255 & 83 & Valine & $\mathrm{C}_{4} \mathrm{H}_{11} \mathrm{NO}_{2}$ & Amino acid \\
\cline { 2 - 7 } & 6 & 4.120 & 74 & Aminoheptanoic acid & $\mathrm{C}_{7} \mathrm{H}_{15} \mathrm{NO}_{2}$ & Amino acid \\
\cline { 2 - 7 } & 7 & 4.345 & 84 & L-Valine & $\mathrm{C}_{5} \mathrm{H}_{11} \mathrm{NO}_{2}$ & Amino acid \\
\hline \multirow{5}{*}{\begin{tabular}{l} 
Water extract in \\
\cline { 2 - 7 }
\end{tabular}} & 1 & 1.625 & 88 & $\begin{array}{c}1,1-\text { Dimethylamino- } \\
\text { 1- butane }\end{array}$ & $\mathrm{C}_{6} \mathrm{H}_{13} \mathrm{~N}$ & Amine \\
\cline { 2 - 7 } & 3 & 2.20 & 82 & $\begin{array}{c}\text { N-tert- } \\
\text { Butylmethylamine }\end{array}$ & $\mathrm{C}_{5} \mathrm{H}_{13} \mathrm{~N}$ & Amine \\
\cline { 2 - 7 } & 4 & 2.265 & 73 & Valienamine & $\mathrm{C}_{7} \mathrm{H}_{13} \mathrm{NO}_{4}$ & Amine \\
\cline { 2 - 7 } & 8 & 4.345 & 82 & Penicillamine & $\mathrm{C}_{5} \mathrm{H}_{11} \mathrm{NO}_{2} \mathrm{~S}$ & Amine \\
\hline
\end{tabular}

Table 2. Chemical composition of snail foot gland (FT) soluble proteins extracts

\begin{tabular}{|l|l|l|l|l|l|l|}
\hline Extracts & Peak & $\begin{array}{l}\text { Retention } \\
\text { time }\end{array}$ & $\begin{array}{l}\text { Similarities } \\
(\%)\end{array}$ & Name of compound & $\begin{array}{l}\text { Molecular } \\
\text { formula }\end{array}$ & $\begin{array}{l}\text { Nature of } \\
\text { compound }\end{array}$ \\
\hline \multirow{2}{*}{$\begin{array}{l}\text { FT extract } \\
\text { in Methanol }\end{array}$} & 1 & 1.63 & 96 & Tert- Butylamine & $\mathrm{C}_{4} \mathrm{H}_{11} \mathrm{~N}$ & Amine \\
\cline { 2 - 7 } & 2 & 2.165 & 87 & N-tert-Butylmethylamine & $\mathrm{C}_{5} \mathrm{H}_{13} \mathrm{~N}$ & Amine \\
\cline { 2 - 7 } & 3 & 2.195 & 91 & Heptylamine & $\mathrm{C}_{7} \mathrm{H}_{17} \mathrm{~N}$ & Amine \\
\cline { 2 - 7 } & 6 & 3.255 & 81 & Penicillamine & $\mathrm{C}_{5} \mathrm{H}_{11} \mathrm{NO}_{2} \mathrm{~S}$ & Amine \\
\cline { 2 - 7 } & 7 & 4.345 & 84 & Penicillamine & $\mathrm{C}_{5} \mathrm{H}_{11} \mathrm{NO}_{2} \mathrm{~S}$ & Amine \\
\hline \multirow{3}{*}{$\begin{array}{l}\text { FT extract } \\
\text { in Water }\end{array}$} & 1 & 1.625 & 83 & Cycloheptanemethylamine & $\mathrm{C}_{8} \mathrm{H}_{17} \mathrm{~N}$ & Amine \\
\cline { 2 - 7 } & 3 & 2.200 & 81 & N-tert-Butylmethylamine & $\mathrm{C}_{5} \mathrm{H}_{13} \mathrm{~N}$ & Amine \\
\cline { 2 - 7 } & 4 & 2.27 & 73 & $\begin{array}{l}\text { dl-Erythro-O- } \\
\text { methylthreonine }\end{array}$ & $\mathrm{C}_{5} \mathrm{H}_{11} \mathrm{NO}_{3}$ & Amine \\
\cline { 2 - 7 } & 7 & 3.265 & 70 & Leucine & $\mathrm{C}_{6} \mathrm{H}_{13} \mathrm{NO}_{2}$ & Amino acid \\
\hline
\end{tabular}

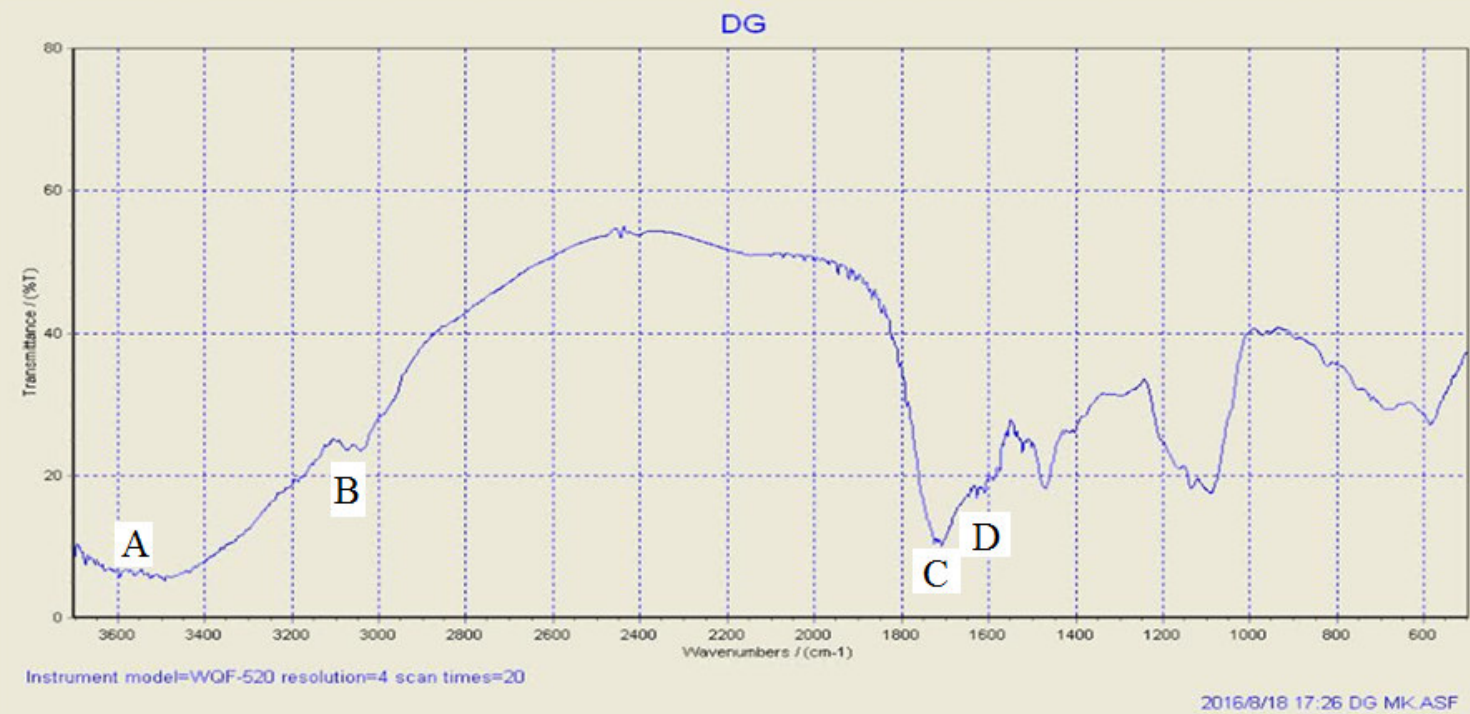

Figure 1. FTIR spectrum of DG soluble protein extract. (A) O-H stretch at $3500 \mathrm{~cm}^{-1}$;(B) N-H stretch at 3100 $\mathrm{cm}^{-1}$; (C) $\mathrm{C}=\mathrm{O}$ stretch at $1700 \mathrm{~cm}^{-1}$; (D) N-H bending at $1600 \mathrm{~cm}^{-1}$. 


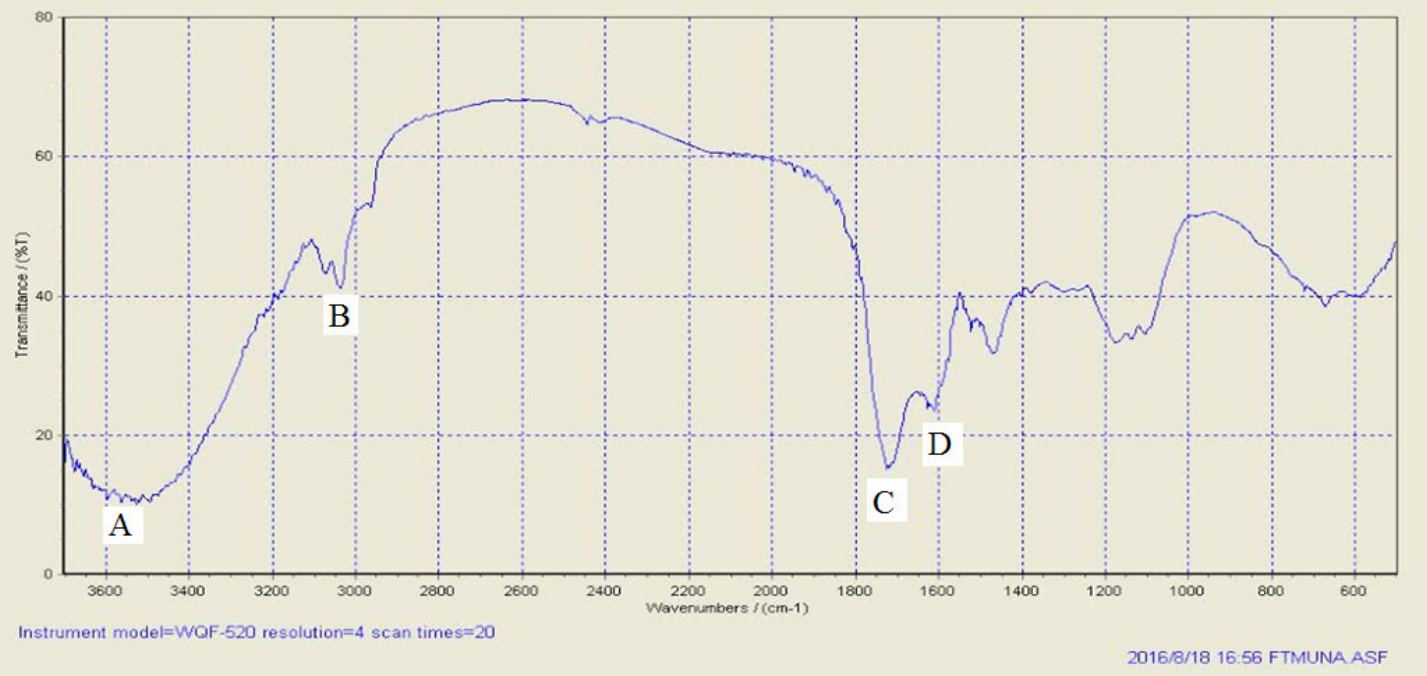

Figure 2. FTIR spectrum of FT soluble protein extract. (A) O-H stretch at $3500 \mathrm{~cm}^{-1}$; (B) N-H stretch at 3100 $\mathrm{cm}^{-1}$; (C) $\mathrm{C}=\mathrm{O}$ stretch at $1700 \mathrm{~cm}-1$; (D) N-H bending at $1600 \mathrm{~cm}^{-1}$.
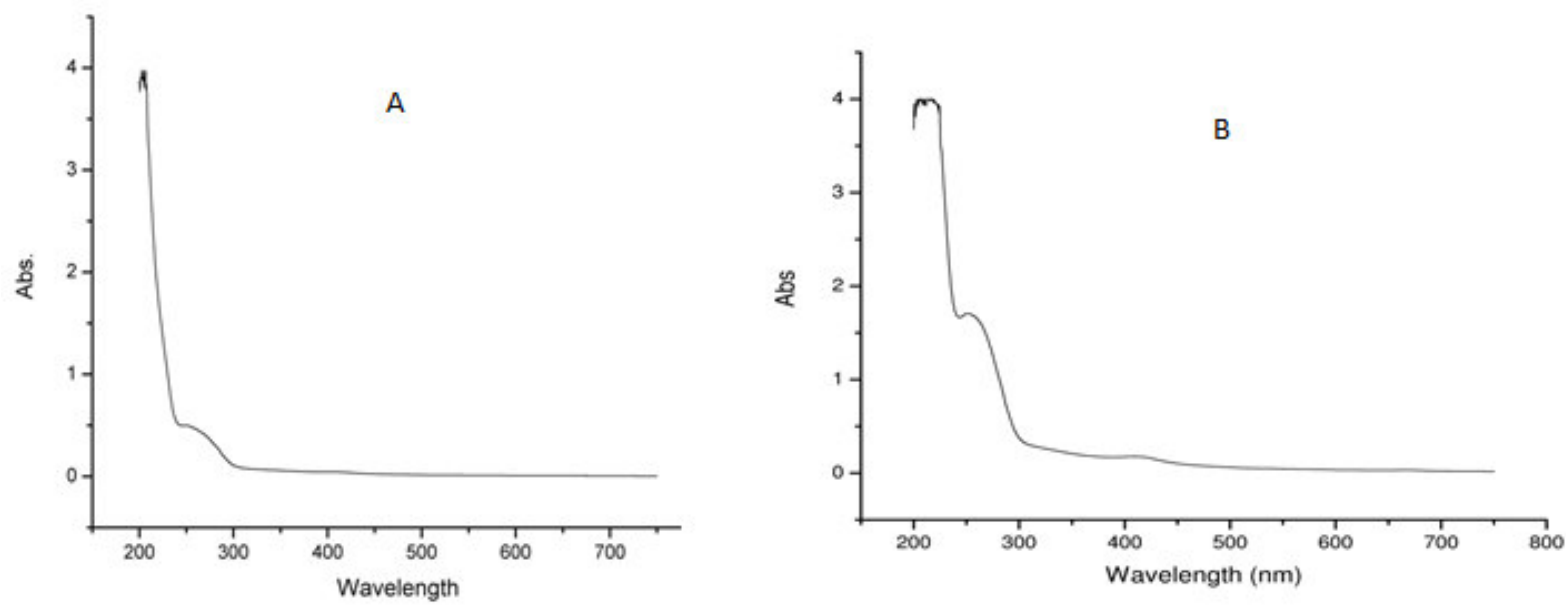

Figure 3. UV spectra of FT (A) and DG (B) soluble proteins extract of Biomphalaria pfeifferi

\section{Conclusion}

In the present study twelve chemical constituents have been identified from Biomphalaria pfeifferi soluble crude protein extracts by Gas Chromatogram-Mass spectrometry (GC-MS) analysis. The presence of various bioactive compounds justifies their medicinal activities. Further studies involving isolation of individual constituents in the soluble proteins and subjecting them to bioassay is highly recommended.

\section{Acknowledgements}

We would like to thank, Ngundi Collins, Sammy Kisara and Esther Kagasifor their technical assistance. Appreciation also goes to National Council for Science Technology and Innovation for the gracious financial support and Institute of Primate Research for allowing the research to be conducted in their facilities.

\section{Disclosure}

The authors are the principal investigators in this study. They take primary responsibility for the paper, as they were in charge of the main laboratory works. The authors report no conflicts of interest in this work.

\section{References}

Abiona, J.A., Akinduti, P.A., Oyekunle, M.A., Osinowo, O.A. \& Onagbesan, A.O.M. (2014). Comparative evaluation of shaemagglutination potential of haemolymph from two species of giant African land snails (Archachatina marginata and Achatina achatina). Fish and Shellfish Immunology, 38, 96 -100. 
Ashraf, Z., Bais, A., Manir, M.M. \& Niazi, U. (2015). Novel penicillin analogues as potential antimicrobial agents; Design, synthesis and docking studies. PLOS ONE 10(8).

Balmer, P., Phillips, H.M., Maestre, A.E., McMonagle, F.A., \& Phillips, R.S. (2000). The effect of nitric oxide on the growth of Plasmodium falciparum, $P$. chabaudi and $P$. berghei in vitroParasite. Parasite Immunology, 22, 97-106.

Ebenebe, C.I. (2000). Mini-livestock production in Nigeria. The present and the future. In Proceedings of the 5th Annual Conference, (ASAN), (pp. 19-22). Port Harcourt, Nigeria.

Fieten, H., Dirksen, K., van den Ingh, T.S., Winter, E.A., Watson, A.L., Leegwater, P.A. \& Rothuizen, J. (2013). D-penicillamine treatment of copper-associated hepatitis in Labrador retrievers. The Veterinary Journal, 196, 522-527.

Fohely, F. \& Suardi, N. (2018). Study the characterization of spectral absorbance on irradiated milk protein. Journal of Physics: Conference Series, 995 012056, 1-10.

Jauréguiberry, S., Paris, L. \& Caumes, E. (2010). Acute schistosomiasis, a diagnostic and therapeutic challenge. Clinical Microbiology and Infection, 16(3), 225-231.

Jeruto, P., Arama,, P., Anyango, B., Nyunja, R.A., Taracha, C. \& Opiyo, S.A. (2017). Morphometric study of Senna didymobotrya (Fresen.) H. S. Irwin and Barneby in Kenya. Journal of Natural Sciences Research, 7 (6), 54-69.

Khattab, H.H., Soliman, A.A., El-Bahy, M.M. \& El-Sayed, N.M. (2010). Value of purified Schistosoma snails antigens in diagnosis of schistosomiasis. Journal of The Arab Society for Medical Research, 5(2),153-158.

Kobia, E.N. (2017). Brine shrimp lethality test and characterization of snail soluble proteins of Biomphalaria pfeifferi as a candidate for vaccine development against Schistosoma mansoni. Journal of Biology, Agriculture and Healthcare, 7(18), 70-76.

Kuria, K.M., Suleman, M.A. \& Yole, D.S. (2019). Immunopathological effects of some Biomphalaria pfeifferi proteins against Schistosoma mansoni infection in BALB/c mice. Journal of. Clinical Immunology and Immunopathology Research, 9(1), 1-12.

Kuria, K.M., Waihenya, R., Kutima, H., Njoki, P. \& Yole, D.S. (2012). Cellular responses against Schistosoma mansoni in immunized Balb/c mice with soluble proteins from intermediate host, Biomphalaria pfeifferi. Tanzania Journal of Health Research, 14(4), 1-13.

Lawal, B., Shittu, O.K., Busari, M.B., Sani, S. \& Aisha, M.I., (2015). Safety evaluation of giant African land snails (Archachatina marginata) haemolymph on hematological and biochemical parameters of Albino rats. Journal of Advances in Medical and Pharmaceutical Sciences, 3(3), 122-30.

Makenzi, A.M., Manguro, L.A.O., Owuor, P.O. \& Opiyo, S.A. (2019a). Chemical constituents of Ocimum Kilimandscharicum Guerke acclimatized in Kakamega Forest, Kenya. Bulletin of the Chemical Society of Ethiopia, 33(3), 527-539.

Makenzi, A.M., Manguro, L.O.A, Owuor, P.O. \& Opiyo, S.A. (2019b). Flavonol glycosides with insecticidal activity from methanol extract of Annona mucosa Jacq. leave. Trends in Phytochemical Research, 3(4), 287296.

Manguro, L, Ogur, J. \& Opiyo, S. (2010a). Antimicrobial constituents of Conyza floribunda. Webmed Central Pharmacology. 1(9), WMC00842.

Manguro, L.O.A., Opiyo, S.A., Asefa, A., Dagne, E. \& Muchori, W.P. (2010b). Chemical constituents of essential oils from three Eucalyptus species acclimatized in Ethiopia and Kenya. Journal of Essential Oil Bearing Plants, 13(5), 561-567.

Manguro, L.O.A., Opiyo, S.A., Herdtweck, E. \& Lemmen, P. (2009). Triterpenes of Commiphora holtziana oleogum resin. Canadian Journal of Chemistry, 87, 1173- 1179.

Ndirangu, E.G., Opiyo, S.A. \& Ng'ang'a, M.W. (2020a). Chemical composition and repellency of Nigella sativa L. seed essential oil against Anopheles gambiae sensu stricto. Trends in Phytochemical Research, 4(2), 7784.

Ndirangu, E.G., Opiyo, S.A. \& Ng'ang'a, M.W., 2020b. Repellent Properties of Compounds and Blends from Nigella sativa Seeds Against Anopheles gambiae. Basic Sciences of Medicine, 9(1), 1-7.

Newman, D.J., Cragg, G.M. \& Snader, K.M. (2003). Natural products as sources of new drugs over the period 1981-2002. Journal of Natural Products, 66, 1022-1037.

NIST 2017.Wiley Registry 11th Edition / NIST 2017 Mass Spectral Library DVD-ROM ISBN: 978-1-119-412236.

Njoroge, P.W. \& Opiyo, S.A. (2019a). Some antibacterial and antifungal compounds from root bark of Rhus natalensis. American Journal of Chemistry, 9(5), 150-158.

Njoroge, P.W. \& Opiyo, S.A. (2019b). Antimicrobial activity of root bark extracts of Rhus natalensisa and Rhus ruspolii. Basic Sciences of Medicine, 8(2), 23-28.

Ochieng, C.O., Ishola, I., Opiyo, S.A., Manguro, L.O.A., Owuor, P.O. \& Wong, K.C. (2013). Phytoecdysteroids from the stem bark of Vitex doniana and their anti-inflammatory effects. Planta Medica, 79, 52-59. 
Ochieng, C.O., Opiyo, S.A., Mureka, E.W. \& Ishola, I.O. (2017). Cyclooxygenase inhibitory compounds from Gymnosporia heterophylla aerial parts. Fitoterapia 119, 168-174.

Ochung, A.A., Manguro, L.A.O., Owuor, P.O., Jondiko, I.O., Nyunja, R.A., Akala, H., Mwinzi, P. \& Opiyo, S.A. (2015). Bioactive carbazole alkaloids from Alysicarpus ovalifolius (Schumach). Korean Society for Applied Biological Chemistry, 58(6), 839-846.

Ochung, A.A., Owuor, P.O., Manguro, L.A.O., Ishola, O.I., Nyunja, R.A., Ochieng, C.O. \& Opiyo, S.A. (2018). Analgesics from Lonchocarpus eriocalyx Harms. Trends in Phytochemical Research, 2(4), 253-260.

Odhiambo, G.O., Musuva, R.M., Atuncha, V.O., Mutete, E.T., Odiere, M.R., Onyango, R.O. \& Mwinzi, P.N.M. (2014). Low levels of awareness despite high prevalence of schistosomiasis among communities in Nyalenda Informal Settlement, Kisumu City, Western Kenya. PLoS Neglected Tropical Diseases, 8(4), 1-8.

Opiyo, S.A. (2019). A review of ${ }^{13} \mathrm{C}$ NMR spectra of drimane sesquiterpenes, Trends in Phytochemical Research, $3(3), 147-180$.

Opiyo, S.A., Manguro, L.A.O., Akinyi, D., Ochung, A.A. \& Ochieng, C.O. (2015). Biopesticidal extractives and compounds from Warburgia ugandensis against maize weevil (Sitophilus zeamais). The Natural Products Journal, 5(4), $236-243$.

Opiyo, S.A., Manguro, L.A.O., Owuor, P.O. \& Ateka, E.M. (2017). Triterpenes from Elaeodendron schweinfurthianum and their antimicrobial activities against crop pathogens. American Journal of Chemistry, (3), 97-104.

Opiyo, S.A., Manguro, L.O.A., Okinda-Owuor, P., Ateka, E.M. \& Lemmen, P. (2011a). 7 alphaAcetylugandensolide and antimicrobial properties of Warburgia ugandensis extracts and isolates against sweet potato pathogens. Phytochemistry. Letters, 4, 161-165.

Opiyo, S.A., Manguro, L.O.A., Owuor, P.O., Ochieng, C.O., Ateka, E.M. \& Lemmen, P. (2011b). Antimicrobial compounds from Terminalia brownii against sweet potato pathogens. The Natural Products Journal, 1, 116120.

Opiyo, S.O., Ogur, J.A., Manguro, L.O.A., Lutz F. Itietze, L.F. \& Schuster, H. (2009). A new sterol diglycoside from Conyza floribunda. South African Journal of Chemistry, 62(4), 9-13.

Owolabi, J., Omogbai, E.K.I. \& Obasuyi, O. (2007). Antifungal and antibacterial activities of the ethanolic and aqueous extract of Kigelia africana (Bignoniaceae) stem bark. African Journal of Biotechnology, 6(14), 882885.

Singh, B.R. (1999). Basic Aspects of the Technique and Applications of Infrared Spectroscopy of Peptides and Proteins. ACS Symposium Series; American Chemical Society: Washington, DC.

Ulagesan, S. \& Kim, H.J. (2018). Antibacterial and antifungal activities of proteins extracted from seven different snails. Applied Sciences, 8, 1362-1370.

WHO (2016). Schistosomiasis: http://www.who.int/mediacentre/factsheets/fs115/en/

Yole, D.S., Pemberton, R., Reid, G.D. \& Wilson, R.A., 1996. Protective immunity to Schistosoma mansoni induced in the olive baboon Papio anubis by the irradiated cercaria vaccine. Parasitology, 112(1), 37-46. 